\title{
Methodological aspects of teaching the basics of intercultural communication
}

\author{
Ryskul Ekinovna Musagulova ${ }^{1,2}$, Irina Arkadievna Chernichenko², Polina Petrovna \\ Yakovleva $^{3}$, Tatyana Nikolaevna Yefremtseva ${ }^{4}$, and Aleksei Yurievich Alipichev ${ }^{5}$ \\ ${ }^{1}$ Financial University under the Government of the Russian Federation, Department of Foreign \\ Languages and Intercultural Communication, Moscow Russia \\ ${ }^{2}$ Russian University of Transport MIIT, Department of Navigation, Moscow, Russia \\ ${ }^{3}$ Russian University of Transport MIIT, Department of Foreign Languages, Moscow, Russia \\ ${ }^{4}$ Russian International Academy for Tourism, Faculty of Tourism Management, Khimki, Russia \\ ${ }^{5}$ Russian State Agrarian University - Moscow Timiryazev Agricultural Academy, Department of \\ Russian and Foreign Languages, Moscow, Russia
}

\begin{abstract}
The article considers the training method for teaching professionally oriented and intercultural communication. The use of training sessions during the study of educational topics in the classroom activates the students' work, helps to consolidate the theoretical knowledge obtained, and motivates students for independent, collective, team work. There is no universally recognized classification of training. The article considers the division of training into three types: educational, personal, and professional. All these three types of training are used by the authors as the final stage of work on a certain topic. The work using the training method is described by the example of teaching students in the discipline "Professionally oriented foreign language", which consists of two modules: professional communication and intercultural communication. The article provides examples of training in the first and second modules. In the first module, training helps to consolidate the so-called "flexible skills", which cover the following topics: leadership, the ability to manage, criticize, resolve conflicts, speak publicly, persuade, negotiate, hold small-talk conversations, be a business person, learn from animals, birds, have business qualities of a leader. In the second module, students get acquainted with training on intercultural communication; learn to deal with people of other cultures, with the peculiarities of cultures, and with mistakes that can be made at the intercultural level.
\end{abstract}

Keywords: training, method, competence, globalization, interactive, form, alternative, skills, effective, communication

\section{Introduction}

*Corresponding author: riskul12@mail.ru 
The dynamically developing market of educational services introduces requirements for training in the field of higher education in the form of competencies required for the disciplines taught.

In the age of globalization, on the one hand, there is a global fusion of cultures, unification, that is, modern multicultural society is being formed. People become the same, eat the same food, watch the same programs, movies, and listen to the same songs. However, it is precisely in the age of globalization that there is an awareness of cultural peculiarities, self-identification, which often leads to intolerance, denial, and conflicts observed today. The processes of globalization, penetrating into national cultures, cause the desire of peoples to protect their language, their culture, and traditions [1,2]. In the opinion of Gerasimova and Ivakhnov, "in the era of global perestroika, the most acute problems of national identity are directly related to the desire of peoples for self-determination and uniqueness, with the desire to defend and preserve their identity" [3].

Colleagues correctly point out that "the key component is the communicative competence, including the ability to communicate with representatives of other cultures, which is provided by the presence of acquisition of general cultural knowledge and skills, as well as practical communication skills, psychological readiness, openness to perception and excellent immersion in the cultural environment" [4].

According to Samuel Hanington, a well-known American political scientist, "the third World War, if it starts, will be a war of cultures and civilizations, not political or economic systems" [5].

\section{Methods}

This article will focus in more detail on the training method that the authors actively use in the discipline "Professionally oriented foreign language".

The use of training in the educational process contributes to the development of the future graduate's personality, forms the elements of his or her future professional activity. There are different definitions of training. According to some researchers, "training is a form of interactive learning, the purpose of which is to develop the competence of interpersonal and professional behavior in communication; it is one of the most important methods in the system of professional training" [6]. From the point of view of other researchers, "training is a special method of obtaining knowledge, which differs from its analogues in that all its participants learn from their own experience of the present moment" [7]. A number of scientists believe that training, in particular intercultural training, is a method of active developmental training that makes it possible to form practical skills of intercultural interaction, prepare for and overcome the negative consequences of cultural shock. Others believe that training is a learning process designed to acquire behavioral, cognitive, and affective skills necessary for effective communication and interaction in different cultures [8].

According to Emelyanov, "the term 'training' should be used to denote methods of developing abilities to learn or master any complex type of activity, in particular communication" [9].

As Pidkasistiy et al. declare, "the training is used both for the formation and improvement of the general readiness of the individual, and for the development of specific communication skills among representatives of those professions that involve intensive contact with other people" $[10,11]$. 


\section{$3 \quad$ Results}

As noted above, the use of the training method will be demonstrated by the example of the discipline "Professionally oriented foreign language". This discipline consists of two modules: professionally-oriented communication and intercultural communication. The training method is used after completing the topics as the final stage, when the content part of training has already been mastered. The advantages of working with training sessions in the classroom at the university are its cyclicity, periodicity, which makes it possible to consolidate and improve the students' theoretical knowledge and practical skills.

In the first module, the following topics are studied: negotiations, the ability to speak publicly, convince, conduct small-talk conversations, modern management, the art of being a leader, the ability to criticize, conflict management, and teamwork.

In the second module, students study the following topics: 5 principles of intercultural communication, features of intercultural communication by country (Russia, the USA, Germany, France, Italy, England, Japan, China, CIS countries, etc.).

In addition to training sessions, different types of work in the classroom are used: computer presentations, Pecha Kucha presentations, working with pictures, with mind maps, project work (short thematic student films), composing thematic tests, crosswords, poems, role-playing games.

There is no single and generally recognized classification of training. One can distinguish the main training types according to the criterion of the direction of impact and changes: skill, socio-psychological, psychotherapeutic, business training. Training can also be divided into educational, personal, and professional. There is also a division into personal and business training. Personal training can be divided, in turn, into psychotherapeutic and personality development training. Business training can be tactical and strategic.

According to the expert on intercultural education and upbringing in higher education Rathje, training is an alternative to training seminars in the framework of the development of intercultural skills [12].

In the first module of the discipline "Professionally oriented foreign language", training helps to develop and strengthen the so-called "flexible skills", which include leadership, the ability to resolve conflicts, to speak, convince, speak publicly, conduct small-talk conversations. Here are some of the training sessions that the authors conduct for the first module.

For example, the leadership training "Locomotives", where there is a leader locomotive (leader) who, with his/her eyes closed, must deliver a train consisting of wagons attached to it (driven) with their eyes open to the destination without colliding with another locomotive with its leader in front, who is also blindfolded. Everyone, if possible, should feel $\mathrm{him} /$ herself both in the role of a leader and in the role of a slave. After the training, during the discussion, one can learn that it was difficult for someone to be a leader with their eyes closed, and for someone to be led with their eyes open, but following the leader from behind, helping him/her lead the train in the right direction.

Teamwork training "Let's join hands, friends" clearly shows and strengthens the skills and abilities to work in a team. The participants stand in a circle with their arms outstretched, at the command of the coach they converge to the center in a tight circle and each takes the palms of the other participants with his/her own hands. Grabbing their hands, they step back slightly. Their task now is to unravel the tangled chain so that a circle of participants holding hands is formed. 
In the second module, training is used to develop intercultural communication: the ability to conduct a dialogue with people of other cultures, knowledge of the peculiarities of one's own and other cultures, differences, taking into account possible mistakes at the intercultural level. Rathje gives the following definition of educational intercultural training "as a method of teaching aimed at developing intercultural competence and pursuing an educational goal with the help of coordinated exercises aimed at preparing for situations of intercultural interaction" [12].

There are a large number of training types in the second module. Students play the training "Bafa Bafa" with great pleasure. This game was invented by American cultural scientists. The participants are divided into two groups. One group represents the people with the "alpha" culture, and the other group represents the people with the "beta" culture. Each group is informed about the norms and values of the cultures and traditions of the selected peoples. After the participants in the game get used to the peculiarities of their peoples' cultures, delegations from each group are sent to another group to get acquainted with the customs and culture of other people. After the end of the game, a joint discussion is held about what they saw, experienced, and felt during their visits to a foreign country. The participants in the training get used to their roles so much that their culture seems to them understandable and better than the culture of their neighbors. The rules of life of other people seem strange to them.

\section{Discussion}

A priority and in-demand competence at the present stage of teaching foreign languages is the requirement to teach not only a foreign language but also the basics of intercultural communication in order to eliminate misunderstandings between participants in communication at the intercultural level [13-15].

According to Samokhina, "we must teach students not only a foreign language, but also effective communication at a professional level, teach not only knowledge of specific language norms, words and rules that have traditionally been considered in the framework of teaching a particular language, but also a broad competence that includes a vast layer of knowledge from various fields, effective business communication requires us not only to understand how to say, but also what to say in a particular case" [16].

\section{Conclusion}

Training is a good addition to traditional professional education. Training makes up for the lack of skills and abilities that are not provided by the education system, helps to rethink the communicative experience, expands knowledge, and contributes to the formation of a more competent interaction with the outside world.

The main requirement for teaching foreign languages, taking into account intercultural communication, is the following triad: motivation, teaching methods, and satisfaction. Successful mastery of the subject is impossible without the positive motivation of the trainees. To increase motivation, one can use technical means, innovative technologies, and a variety of modern teaching methods and techniques, such as project methods and training sessions. It is necessary to bring the content and methods closer to the practical needs of the trainees so that they get satisfaction from studying the discipline. Training is an interactive form of teaching, the main purpose of which is the rapid formation of skills, the 
assimilation of information, and the change of personal attitudes. The use of training in the classroom helps to increase the students' motivation and emotionality [17].

\section{References}

1. R.E. Musagulova, River Transp (XXIst cent), 6(65), 70-73 (2013)

2. S. Xi, E3S Web of Conf, 257(2), 02075 (2021). https://doi.org/10.1051/e3conf/202125702075

3. I.A. Gerasimova, V.Yu. Ivakhnov, Cult Civil, 2, 66-67 (2017). https://doi.org/10.22412/1993-7768-11-2-9

4. E.A. Fedorova, et al., Int J Eng Adv Tech, 9(1), $4532-4535$ (2019)

5. Hanington S. Stolknovenie tsivilizatsii [Clash of Civilizations] (AST, Moscow, 2006)

6. G.M. Kodzhaspirova, A.Yu. Kodzhaspirova, Pedagogicheskii slovar [Pedagogical Dictionary] (Akademiya, Moscow, 2005)

7. S. Gladyshev, Kak vesti sebya na treninge [How to Act at Training]. Accessed on: October 21, 2021. [Online]. Available: https://hr-portal.ru/article/kak-vesti-sebya-na-treninge

8. Raj Aggarwal. Cross cultural Communication and IB Teaching. Journal of Teaching in international Business 31(3):185-190. DOL:10.1080/08975930.2020.1841855

9. Yu.M. Emelyanov, Aktivnoe Sotsialno-Psikhologicheskoe Obrazovanie [Active Social-Psychological Education] (Leningrad Univ Press, Leningrad, 1985)

10. P.I. Pidkasistiy, L.M. Fridman, M.G. Garunov, Psikhologo-didakticheskii spravochnik dlya prepodavatelei vysshei shkoly [Psychological and Didactical Reference Book for Higher School Teachers] (Pedagogical Community of Russia, Moscow, 1999)

11. S.M. Croucher, Front Comm, 5, 61 (2020). https://doi.org/10.3389/fcomm.2020.00061

12. S. Rathje, Training/Lehrtraining, in A. Weidemann, J. Straub, S. Nothnagel (eds), Wie lernt man die interkulturelle Kompetenz? Theorien, Methoden und Praxis in der Hochschulausbildung, 215-240 (Verlag, 2010)

13. B.J. Hurn, B. Tomalin, Cross-cultural Communication. Theory and Practice (Palgrave Macmillan, London, 2013). https://doi.org/10.1057/9780230391147

14. S.G. Ter-Minasova, Yazyk i mezhkulturnaya kommunikatsiya [Language and Intercultural Communication] (Slovo, Moscow, 2008)

15. T. Zhiping, Learn Edu, 9(2), 101-102 (2020). http://dx.doi.org/10.18282/1-e.v9i2.1414

16. T.S. Samokhina, Effektivnoe delovoe obshchenie v kontekste razlichnykh kultur i obstoyatelstv [Effective Business Communication in Contexts of Different Cultures and Circumstances] (R. Valent, Moscow, 2005)

17. H. Hartono, S. Suparto, A. Hassan, Ling Cult Rev, 5(1), 93-103 (2021). https://doi.org/10.37028/lingcure.v5n1.835 